\title{
An Analysis of the Dynamic Relationships Between the South African Equity Market and Major World Equity Markets*
}

\author{
Asjeet S. Lamba \\ The University of Melbourne, Australia \\ Isaac Otchere \\ The University of Melbourne, Australia
}

This paper provides the first comprehensive analysis of the dynamic relationships between the South African and major world equity markets during May 1988 - May 2000. Using a multivariate cointegration framework and vector error-correction modeling the results indicate that there is a long-run relationship between the South African market and major developed markets. Over the full sample period, the US, Canada and Australia exert the most influence on South Africa, while the influence of Japan is minimal. The subperiod analysis shows that, during the Apartheid period, a long-run equilibrium relationship between South Africa and the major developed markets did not exist. In contrast, during the post-Apartheid period, the long-run relationship has become strong and statistically significant for all the major developed markets, except Japan. Overall, the results imply that South Africa is now much more economically and financially integrated with major developed markets, and that the removal of Apartheid has played a significant role in this process (JEL F30, F36, G15).

Keywords: co-integration, emerging markets, South Africa, vector errorcorrection model.

\section{Introduction}

The interest in studying the dynamic relationships among major developed markets gathered considerable momentum following the

\footnotetext{
${ }^{*}$ We are grateful to two anonymous referees and P. Theodossiou (the Editor) for their helpful comments. We also thank John Sequeira for useful discussions. We are responsible for any remaining errors.
}

(Multinational Finance Journal, 2001, vol. 5, no. 3, pp. 201-224)

CMultinational Finance Society, a nonprofit corporation. All rights reserved.

DOI: $10.17578 / 5-3-3$ 
October 1987 global stock market crash, and even more so, following the Asian financial crisis in 1997-98. Several researchers have examined the interdependence among developed and developing markets, and the main findings of these studies can be summarized as follows. ${ }^{1}$ First, the US generally influences most markets in the European and Pacific-Basin regions, while markets in these regions have little influence on the US market. Second, Japan, the second largest equity market, has little influence on other equity markets. Third, the UK has some influence on markets in Japan, Australia, Hong Kong and Canada. Finally, the linkages among Pacific-Basin equity markets can be attributed to the direct and indirect influences of the US market.

While previous researchers have examined the linkages among equity markets in Asia, Europe, North America and Latin America, markets in the African region have received little research interest. Since the 1980s, most sub-Saharan African countries have deregulated their capital markets and removed barriers to international investment. Most countries in this region have also embarked on IMF and World Bank sponsored structural adjustment programs. These programs have resulted in the deregulation of financial systems, liberalization of financial markets, development of stock exchanges, privatization of former stateowned enterprises, and the easing of barriers to the flow of capital from industrialized countries. Thus, it is reasonable to expect that the more developed African markets have become more integrated with major world equity markets.

This paper analyzes the dynamic relationships between the South African equity market and major world equity markets during May 1988 - May 2000. South Africa presents an interesting case given its relative isolation from the world's political and economic systems during the Apartheid years. Following the gradual easing and then the formal removal of Apartheid during 1989-94, South Africa has made a dramatic transition where it is more than likely that its equity market has become more integrated with major developed equity markets. This expectation is empirically verified by analyzing the causal relationship between South Africa and major developed markets, as well as the role Apartheid may

1. See, for example, Eun and Shim (1989), Cheung and Mak (1992), Arshanapalli and Doukas (1993), Gjerde and Sættem (1995), Friedman and Shachmurove (1997), Liu and Pan (1997), Masih and Masih (1997), Meric and Meric (1997), Janakiramanan and Lamba (1998), and Niarchos, et al. (1999). 
have played in influencing South Africa's financial integration with these markets.

From the perspective of foreign investors, the South African market is important because it is the largest and most developed market in the African region. Thus, to be exposed to equity markets in this region it is important for foreign investors to have exposure to the South African market. In addition, as shown in table 2, the relatively low return correlations between South Africa and major developed markets point to the substantial risk diversification benefits that foreign investors can achieve by investing in the South African market. This is particularly relevant in the context of recent findings by researchers who document a reduction in portfolio diversification opportunities across different markets. For example, Meric and Meric (1997) find that the comovement between the US and European equity markets has increased significantly following the $1987 \mathrm{crash}$, implying reduced diversification benefits. Taking these factors into account, a detailed examination of the evolution of the dynamic relationships between the South African market and major world equity markets becomes topical and relevant.

To examine these dynamic relationships, a multivariate cointegration framework and vector error-correction model (VECM) is used to analyze the causal influence of the major developed markets on the South African market. This method allows any long-run equilibrium relationships between the markets to be separated from the short-run causal effects. The results show that there is a long-run relationship between the South African market and major developed markets. Also, while the US, Canada and Australia exert the most influence on the South African market, the influence of Japan is minimal. The sub-period analysis shows that the strength of the long-run equilibrium relationship and the short-run causal effects on the South African market by the major developed markets has changed since the removal of the Apartheid regime. Specifically, during the Apartheid period there is no long-run equilibrium relationship between the South African market and the major equity markets. In contrast, since the removal of Apartheid, this long-run relationship has become quite strong and statistically significant.

The remainder of this paper is organized as follows. Section II describes the data and methodology used. Section III presents and analyzes the results and Section IV concludes the paper. 


\section{Data and Method}

\section{A. Data}

The dynamic relationships between the major developed markets and the South African market are examined during May 1988 - May 2000, a period that coincides with the deregulation of capital markets in South Africa. The choice of which developed equity markets to include in the analysis is determined mainly by the expected economic and financial linkages among these markets and South Africa. Thus, the developed equity markets included in the analysis are Australia, Canada, France, Germany, Japan, the UK, and the US. Table 1 provides some summary information on the markets examined and shows that compared to these developed equity markets, South Africa is a relatively small market (panel B). ${ }^{2}$

Table 2 provides some descriptive statistics for the continuously compounded daily returns in each market along with the correlation coefficients among daily market returns. The daily return attributes of South Africa are similar to those for the developed markets examined, and these returns exhibit positive, but relatively low, correlations with the returns of all the major developed markets. Interestingly, the highest correlations are with Australia and Germany, followed by the UK. The correlation with the US market's (lagged) return is also positive, but lower in magnitude.

These descriptive statistics point to the potential risk diversification benefits that foreign investors can achieve because of the low correlations between the major foreign markets and South Africa. As mentioned in section I, previous studies have documented an increase in correlation among the major developed equity markets. ${ }^{3}$ The results of these studies imply that the benefits of international diversification are reducing because of increased return correlations. Hence, the low correlations between South Africa and major developed markets suggest that foreign investors can achieve substantial risk diversification benefits with an exposure to the South African market.

2. Data on daily market indices, measured in local currency terms, were obtained from Bloomberg. All data were screened for errors using filter tests and no major discrepancies were found.

3. See, for example, Oldier and Solnik (1993), Solnik, Boucrelle and Le Fur (1996), and Meric and Meric (1997). 
TABLE 1. Summary Information on Markets Analyzed

\begin{tabular}{|c|c|c|c|}
\hline Country & Index & Local Time & $\begin{array}{l}\text { Greenwich } \\
\text { Mean Time }\end{array}$ \\
\hline \multicolumn{4}{|c|}{ A. Market opening and closing times in local time and Greenwich Mean Time } \\
\hline Australia & All Ordinaries Index & $10: 00-16: 00$ & 00:00 - 06:00 \\
\hline Canada & TSE 300 Index & $09: 30-16: 00$ & $14: 30-21: 00$ \\
\hline France & CAC Index & $10: 00-17: 00$ & 09:00 - 16:00 \\
\hline Germany & DAX Index & $09: 00-17: 30$ & $08: 00-16: 30$ \\
\hline \multirow[t]{2}{*}{ Japan } & Nikkei 225 Index & 09:00 - 11:00 & 00:00 - 02:00 \\
\hline & & $12: 30-15: 00$ & $03: 30-06: 00$ \\
\hline South Africa & JSE Overall Index & $09: 30-16: 00$ & $07: 30-14: 00$ \\
\hline UK & Financial Times 100 Index & $08: 00-16: 30$ & $08: 00-16: 30$ \\
\hline \multirow[t]{4}{*}{ US } & Standard \& Poor's 500 Index & $09: 30-16: 00$ & $14: 30-21: 00$ \\
\hline & Total Market & Total Value & Number of \\
\hline & Capitalization & Traded & Domestic \\
\hline & (US\$ Mill.) Percent & (US\$ Mill.) Percent & Comp. Percent \\
\hline
\end{tabular}

B. Total market capitalization, total value traded and number of domestic listed companies at the end of $1998^{\text {a }}$

$\begin{array}{lrrrrrr}\text { Australia } & 874,283 & 3.2 & 407,420 & 1.8 & 1,162 & 2.4 \\ \text { Canada } & 543,394 & 2.0 & 372,082 & 1.6 & 1,384 & 2.9 \\ \text { France } & 991,484 & 3.6 & 572,151 & 2.5 & 711 & 1.5 \\ \text { Germany } & 1,093,962 & 4.0 & 1,390,798 & 6.1 & 741 & 1.6 \\ \text { Japan } & 2,495,757 & 9.1 & 948,522 & 4.1 & 2,416 & 5.1 \\ \text { South Africa } & 170,252 & 0.6 & 58,444 & 0.3 & 668 & 1.4 \\ \text { UK } & 2,374,273 & 8.6 & 1,167,382 & 5.1 & 2,399 & 5.1 \\ \text { US } & 13,451,352 & 49.0 & 13,148,480 & 57.5 & 8,450 & 17.8 \\ & & & & & & \end{array}$

Note: ${ }^{a}$ Source: Emerging Markets Data Base, 1999. The Percent columns provide information on a particular market's share relative to the world total at the end of 1998. 


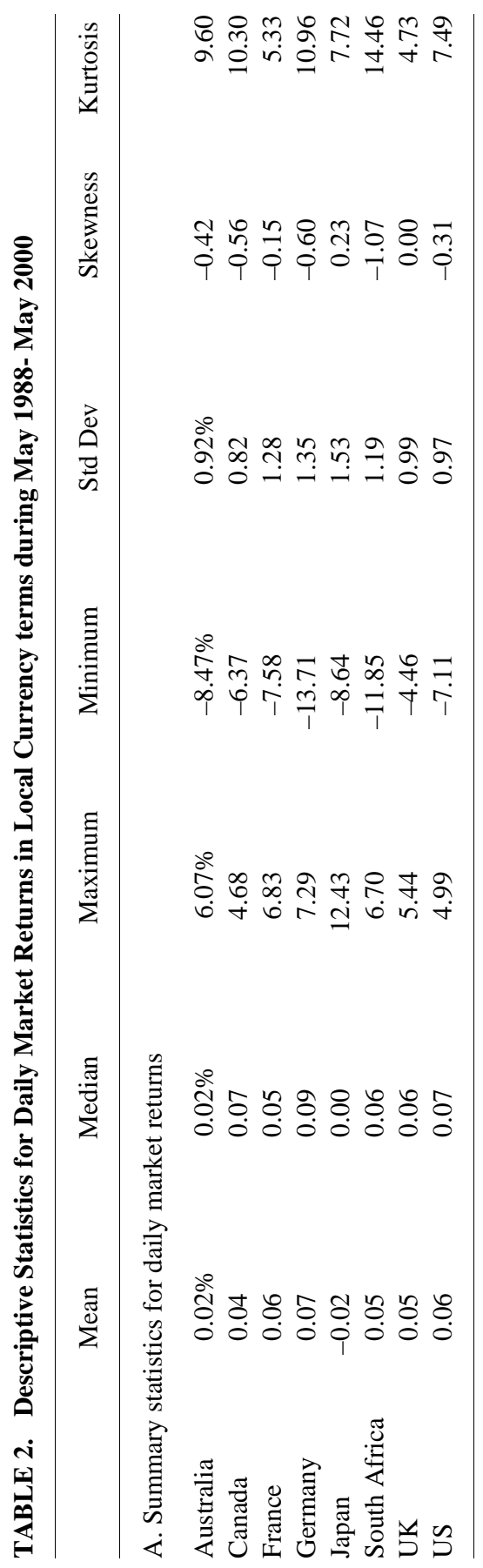




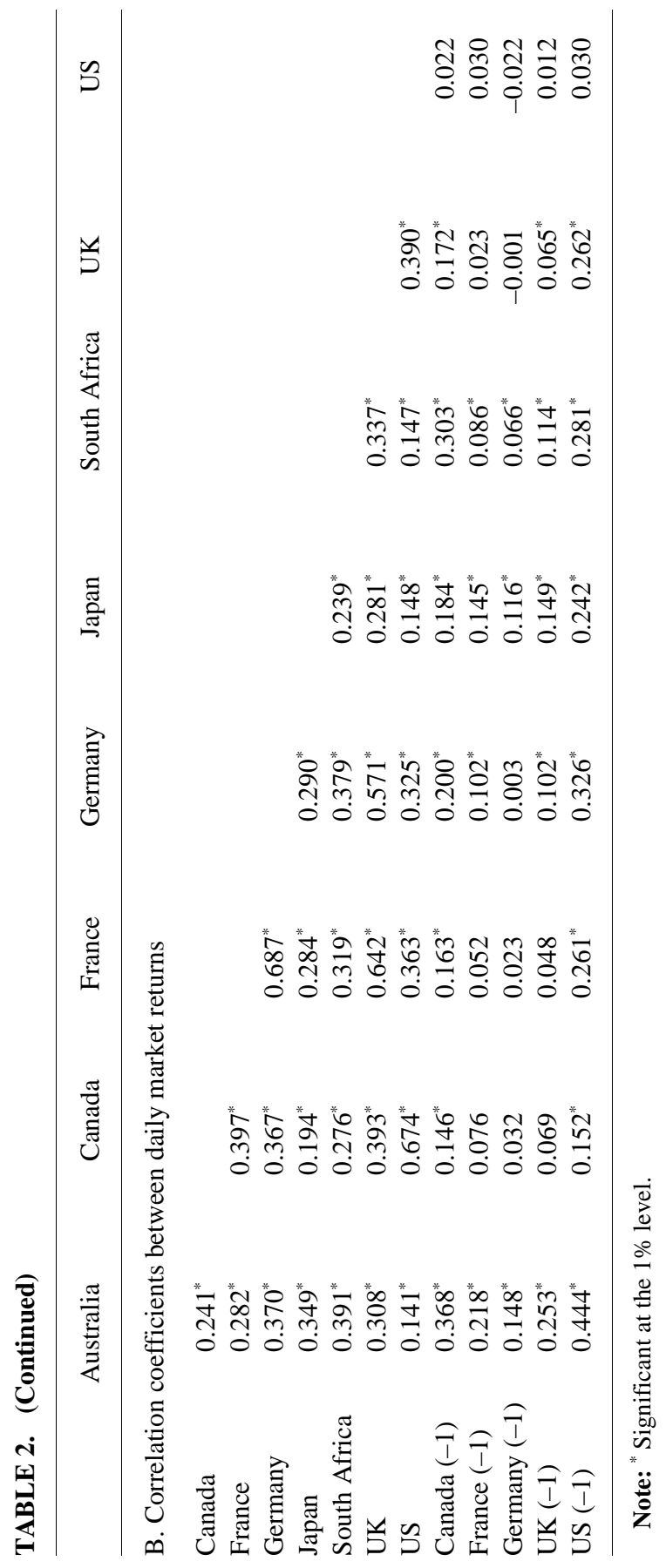




\section{B. Method}

The use of ordinary least squares or Granger-causality estimation methods involving first differences of time series to examine the causal relation among specific variables can result in loss of significant long-run information embodied in these time series. If the time series are cointegrated, then the estimation method should be expanded to include an error-correction term to capture the system's adjustment towards the underlying long-run relationship. In general, two variables are cointegrated when a linear combination of the variables is stationary, even though each may individually be non-stationary. Since nonstationary variables do not return to their long-run average values following a disturbance, it is important to convert them to stationary processes, otherwise regressing a non-stationary $I(1)$ process on another I(1) process can generate spurious results. If a time series contains a stochastic trend, it is said to be integrated of order $d$, i.e. $I(d)$. Differencing the series $d$ times yields a stationary series. The time series of many macroeconomic variables, including market index series, are likely to be non-stationary in levels but stationary in first differences and are therefore likely to be $I(1)$ processes. Thus, the dynamic relationships between the South African market and major world equity markets are analyzed using a vector error-correction model. The model allows for an examination of the long-run equilibrium relationships between the South African equity market and major developed markets as well as their short-run adjustments over time.

In order to correctly specify the dynamic relationships, the behavior of the market index series is examined first to determine whether they are stationary. If they are found to be non-stationary, then an examination of whether they are cointegrated is conducted. The augmented Dickey-Fuller (ADF) test is used on the market index levels and their first differences to test for unit roots in the data (Dickey and Fuller [1979, 1981]). To perform the ADF test, for each market index series, the following regression is estimated:

$$
Y_{t}=\alpha_{0}+\alpha_{1} t+\rho Y_{t-1}+\sum_{j=2}^{p} \gamma_{j} Y_{t-j}+\varepsilon_{t}
$$

where $Y_{t}$ is a time series of daily market index data, $t$ is a time trend, and 
TABLE 3. Stationarity Tests for Market Index Levels and First Differences (Market Returns) Based on the Augmented Dickey-Fuller (ADF) Test Statistic $^{\mathrm{a}}$

\begin{tabular}{lcc}
\hline Market & Market Index Levels & Market Returns \\
\hline Australia & -0.264 & $-24.316^{*}$ \\
Canada & -1.072 & $-24.352^{*}$ \\
France & -1.764 & $-23.366^{*}$ \\
Germany & -0.965 & $-22.570^{*}$ \\
Japan & -1.311 & $-23.317^{*}$ \\
South Africa & -1.379 & $-8.197^{*}$ \\
UK & -0.131 & $-24.862^{*}$ \\
US & -1.033 & $-26.463^{*}$ \\
\hline
\end{tabular}

Note: ${ }^{\text {a }}$ The critical values for the augmented Dickey-Fuller test statistic are -2.863 and -3.436 at the $5 \%$ and $1 \%$ levels, respectively. ${ }^{*}$ Significant at the $1 \%$ level.

$\mathcal{E}_{t}$ is a white noise process. The time series is non-stationary if $\rho=1$. After examining the stationarity of each market's index series the stationarity of the first differences $\left(\Delta Y_{t}\right)$ is examined. Table 3 reports the results which show that the hypothesis of non-stationarity in the market indices cannot be rejected. However, the hypothesis of non-stationarity in first differences is rejected for all markets implying that the variables are integrated of order one, i.e., $I(1)$.

Since the market index series are integrated of the same order, cointegration analysis is used to determine whether the index series become stationary in a linear combination. This test is performed using the Johansen (1991) method which involves estimating the following unrestricted vector autoregressive (VAR) model: ${ }^{4}$

$$
Y_{t}=A_{0}+\sum_{j=1}^{p} A_{j} Y_{t-j}+\varepsilon_{t}
$$

where $Y_{t}$ is an $\mathrm{n} \times 1$ vector of non-stationary $I(1)$ variables, $A_{0}$ is an $\mathrm{n} \times$

4. An alternative method would be to use Engle and Granger's (1987) two-step cointegration test. Although relatively easy to implement, this test is not used because it assumes only one cointegrating vector and does not allow for potential feedback effects (Enders, 1995). 
1 vector of constants, $p$ is the number of lags, $A_{j}$ is an $\mathrm{n} \times \mathrm{n}$ matrix of estimable parameters, and $\mathcal{E}_{\mathrm{t}}$ is an $\mathrm{n} \times 1$ vector of independent and identically distributed (i.i.d.) innovations. This VAR model can be rewritten as:

$$
\Delta Y_{t}=A_{0}+\sum_{j=1}^{p-1} \Gamma_{j} \Delta Y_{t-j}+\Pi Y_{t-1}+\varepsilon_{t}
$$

where

$$
\Gamma_{j}=-\sum_{i=j+1}^{p} A_{i}
$$

and

$$
\Pi=\sum_{j=1}^{p} A_{j}-I
$$

$\Delta$ is the difference operator, and $I$ is an $\mathrm{n} \times \mathrm{n}$ identity matrix.

The rank of the matrix $\Pi$ determines the number of cointegrating vectors since the rank of $\Pi$ is equal to the number of independent cointegrating vectors. Thus, if the rank of $\Pi$ equals 0 , the matrix is null and equation 3 becomes the usual VAR model in first differences. If the rank of $\Pi$ is $r$ where $r<n$, then there exist $r$ cointegrating relationships in the above model. In this case, the matrix $\Pi$ can be rewritten as $\Pi=$ $\alpha \beta^{\prime}$ where $\alpha$ and $\beta$ are $\mathrm{n} \times \mathrm{r}$ matrices of rank $r$. Here, $\beta$ is the matrix of cointegrating parameters and $\alpha$ is the matrix of weights with which each cointegrating vector enters the above VAR model.

Johansen (1991) provides two different test statistics that can be used to test the hypothesis of the existence of $r$ cointegrating vectors, namely, the trace test and the maximum eigenvalue test. The trace test statistic tests the null hypothesis that the number of distinct cointegrating relationships is less than or equal to $r$ against the alternative hypothesis of more than $r$ cointegrating relationships, and is defined as:

$$
\lambda_{\text {trace }}(r)=-T \sum_{j=r+1}^{\rho} \ln \left(1-\hat{\lambda}_{j}\right)
$$

where $T$ is the number of observations and the $\lambda_{j} \mathrm{~s}$ are the eigenvalues of $\Pi$ in equation (3). The maximum eigenvalue test statistic tests the null hypothesis that the number of cointegrating relationships is less than or 
TABLE 4. Johansen's Test for Multiple Cointegrating Vectors for the Long-Run Relationship Among Market Returns ${ }^{\mathrm{a}}$

\begin{tabular}{lcrr}
\hline & & \multicolumn{2}{c}{ Critical Values } \\
Null Hypothesis & Trace Test Statistic & $5 \%$ & $1 \%$ \\
\hline A. Trace Test & & & \\
No Cointegrating Vector, $r=0$ & $192.33^{* *}$ & 156.00 & 168.36 \\
At Most 1 Cointegrating Vector, $r £ 1$ & $133.96^{* *}$ & 124.24 & 133.57 \\
At Most 2 Cointegrating Vectors, $r £ 2$ & 82.38 & 94.15 & 103.18 \\
At Most 3 Cointegrating Vectors, $r £ 3$ & 49.90 & 68.52 & 76.07 \\
\hline
\end{tabular}

\begin{tabular}{lccr}
\hline & \multicolumn{2}{c}{ Maximum Eigenvalue } & \multicolumn{2}{c}{ Critical Values } \\
\cline { 3 - 4 } Null Hypothesis & Test Statistic & $5 \%$ & $1 \%$ \\
\hline B. Maximum Eigenvalue Test & & & \\
No Cointegrating Vector, $r=0$ & $58.36^{* *}$ & 51.42 & 57.69 \\
At Most 1 Cointegrating Vector, $r £ 1$ & $51.57^{*}$ & 45.28 & 51.57 \\
At Most 2 Cointegrating Vectors, $r £ 2$ & 32.49 & 39.37 & 45.10 \\
At Most 3 Cointegrating Vectors, $r £ 3$ & 22.45 & 33.46 & 38.77 \\
\hline
\end{tabular}

Note: ${ }^{a} r$ denotes the number of cointegrating relationships. The optimal lag structure of the vector autoregression (VAR) model is selected by minimizing the Akaike Information

equal to $r$ against the alternative of $r+1$ cointegrating relationships, and is defined as:

$$
\lambda_{\max }(r, r+1)=-T\left(\ln \left(1-\hat{\lambda}_{r+1}\right)\right)
$$

The critical values for both tests are obtained from Osterwald-Lenun (1992). The results from the Johansen cointegration tests appear in table 4. ${ }^{5}$ Both test statistics lead to the rejection of the null hypothesis of no

5. The selection of the order of lags in the Johansen test and, subsequently, the errorcorrection model is important, since the choice of the lag can have an important impact on the outcome of these tests (Enders, 1995). The following criteria suggested by Engle and White (1999) to select the optimum lag structure are used: (i) residual diagnostic tests to ensure the regression residuals are white noise, (ii) the Akaike Information Criterion (or Schwarz Criterion) to optimize the goodness of fit, and (iii) the statistical significance of coefficients of lagged variables. 
cointegration. However, the two test statistics give conflicting evidence on the number of cointegrating vectors. Given this, the more conservative position is adopted that, at the $1 \%$ level, there is only one cointegrating vector in the error-correction model estimated below.

Since the market index series have a single cointegrating relationship, they have a tendency to move together in the long-run even though they may experience short-run deviations from the common equilibrium path. Thus, the causal relationships between the South African market and the major developed markets are examined using the following errorcorrection model:

$$
\begin{gathered}
\Delta S A_{t}=a_{0}+\gamma Z_{t-1}+\sum_{j=1}^{p} \alpha_{j} \Delta S A_{t-j}+\sum_{j=1}^{p} \eta_{j} \Delta A U_{t-j}+\sum_{j=1}^{p} \varsigma_{j} \Delta C A_{t-j} \\
+\sum_{j=1}^{p} \phi_{j} \Delta F R_{t-j}+\sum_{j=1}^{p} \theta_{j} \Delta G E_{t-j}+\sum_{j=1}^{p} \lambda_{j} \Delta J P_{t-j}+\sum_{j=1}^{p} \xi_{j} \Delta U S_{t-j} \\
+\sum_{j=1}^{p} \varphi_{j} \Delta U K_{t-j}+\eta_{t,}
\end{gathered}
$$

where

$$
Z_{t-1}=S A_{t-1}-\beta_{1} A U_{t-1}-\beta_{2} C A_{t-1}-\beta_{3} F R_{t-1}-\beta_{4} G E_{t-1}-\beta_{5} J P_{t-1}
$$

$a_{0}$ is the constant representing a linear trend and $\eta_{t}$ is the error term representing unanticipated movements in the South African index, $\Delta S A_{t}$. $Z_{t-1}$ contains the error-correction term which is derived from the longrun cointegrating relationship among the market indices using the Johansen procedure.

Within the framework of the error-correction model, Engle and Granger (1987) show that deviations from the long-run relationship should result in adjustments over time. The model thus expresses changes in the South African index in terms of the lagged changes of the market indices examined and a cointegrating error term. The economic intuition behind the specification in equation 7 is that if the South African market and the other markets are cointegrated, part of the current changes in the South African index reflects the "alignment" that the South African market attempts to achieve with the trends in other markets. 
The hypothesis regarding the causal relationship between the South Africa equity market and major developed markets is tested by examining the significance of the $F$-statistics for the joint lagged values of changes in these equity markets and a $t$-statistic for the errorcorrection term. The finding of a significant $t$-statistic on the errorcorrection term suggests a long-run causal relationship while a significant $F$-statistic implies a short-term causal effect. The lack of significance of both the $t$-statistic and the $F$-statistic indicates that movements in the South African market are independent of movements in the developed markets examined.

\section{Results and Discussion}

\section{A. Results for the Full Period}

The results for the full sample period appear in table 5. Panel A shows the influence of the developed markets on South Africa while panel B shows whether there is a bi-directional causality between South Africa and these markets. A seven-lag specification is chosen in the VECM since this lag length minimizes the Akaike Information Criterion (AIC). The error-correction term is found to be significant at the $1 \%$ level, indicating that there is a long-run causal relationship between the South African market and the major developed markets. This suggests that the South African market is endogenous in the long-run and that short-run deviations from the long-run equilibrium will prompt adjustment to a longrun equilibrium path. ${ }^{6}$ An examination of the individual $t$-statistics of the lagged index changes in the major developed markets reveals that contemporaneous changes in the South African market index are Granger-caused by changes in the major developed markets during the previous day. The $F$-statistics indicate that the South African market is Granger-caused by all the major developed markets, except Japan. Among these markets, the US, Canada and Australia exert the most influence on South Africa. The finding that Japan, the world's second largest equity market, does not influence the South African market is

6. This finding is consistent with earlier evidence provided by Philippatos, Christofi and Christofi (1983) who find long-run intertemporal stability among fourteen developed equity markets. 


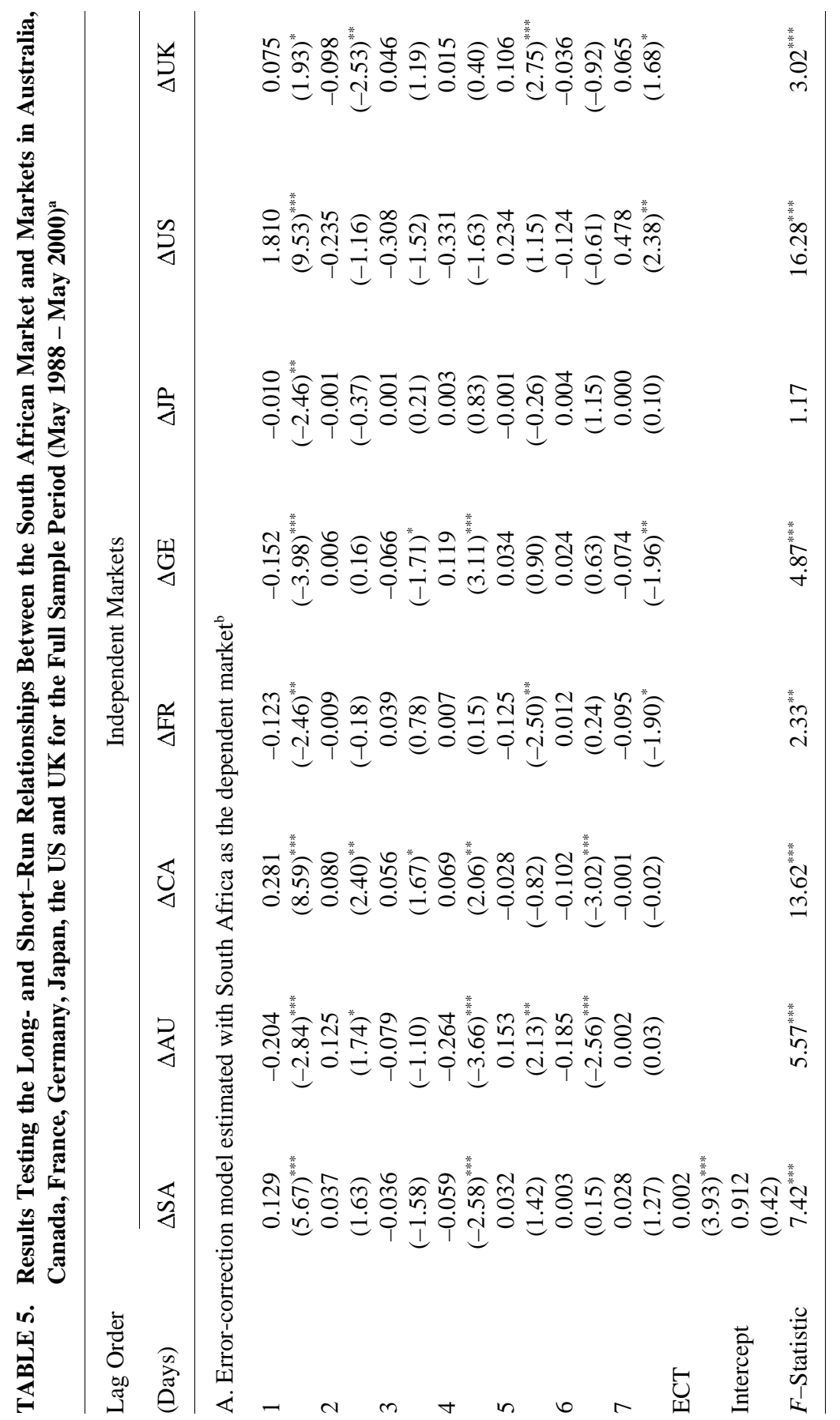




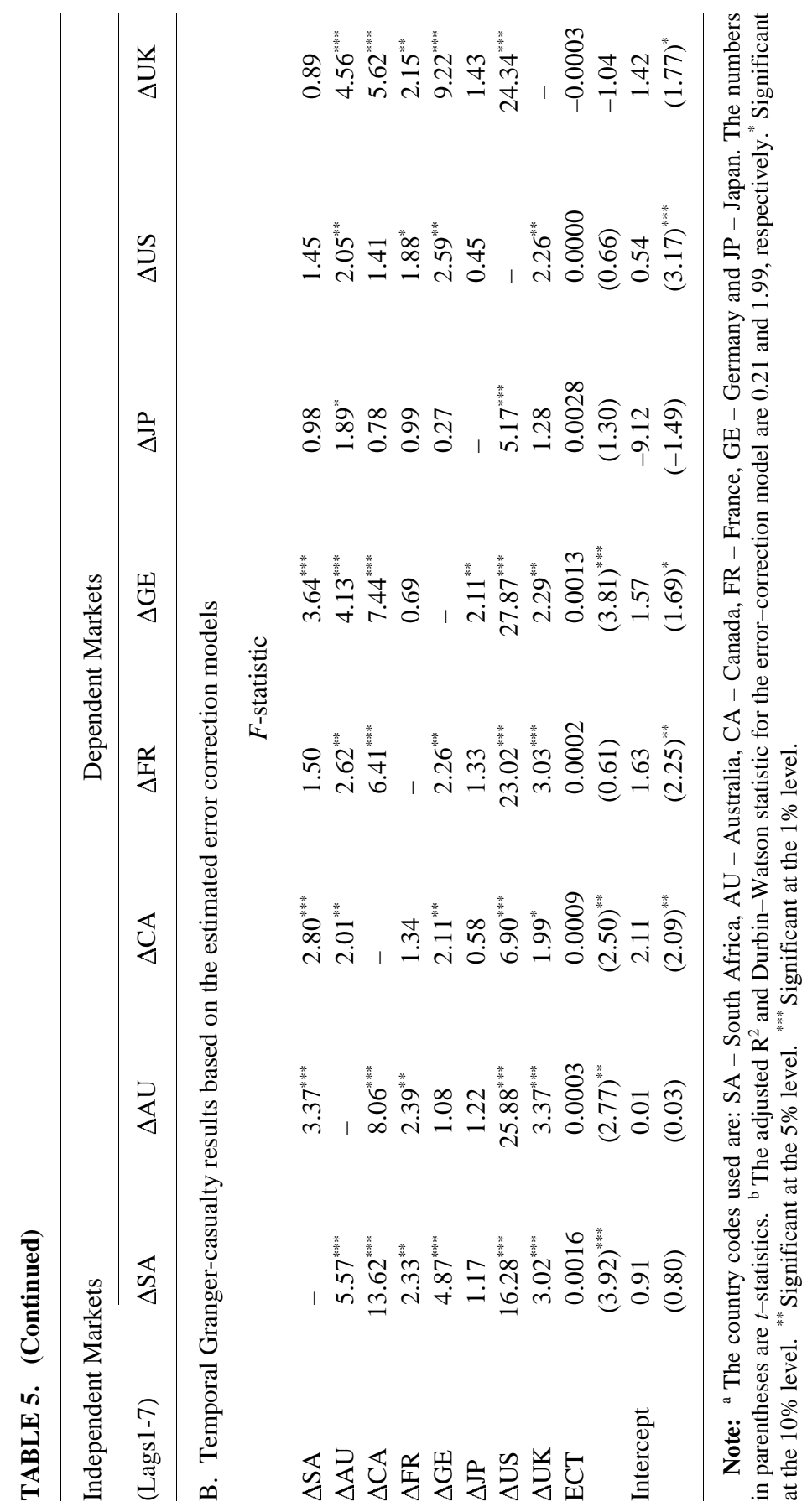


consistent with the evidence documented by Liu and Pan (1997), Janakiramanan and Lamba (1998) and Christofi, Pericli and Nishiyama (2001) who find that Japan also does not influence markets in the Pacific-Basin region.

The results presented thus far suggest that a uni-directional causality exists between the South African market and the major developed markets, with these markets (excluding Japan) leading the South African market. However, it is possible that a bi-directional relationship also exists between the South African market and the major developed markets. To ascertain whether a bi-directional relationship exists, separate vector error-correction models are estimated with each market as the dependent variable. The summary results from these VECMs are presented in panel B of the table and show that a feedback relationship exists between South Africa and Germany. ${ }^{7}$ In addition, there is bidirectional causality between South Africa and markets in the resourcebased economies of Australia and Canada.

\section{B. Results for the Apartheid and Post-Apartheid Periods}

In this section, the hypothesis that the strength of the equilibrium longrun relationship and the short-run causal effects between the South African market and the major developed markets has changed since the removal of Apartheid is examined. For this analysis the overall sample period is divided into two sub-periods. The first sub-period spans May 1988 - December 1993 and corresponds to the period during which several Apartheid reforms took place and ends four months prior to the election of Nelson Mendela as president in April 1994. ${ }^{8}$ The second subperiod, spanning August 1994 - May 2000, corresponds to the postApartheid period and starts four months following the election of Nelson Mendela as president. ${ }^{9}$

7. Detailed results from this analysis are available from the authors upon request. (1998).

8. For details on the types of reforms that took place during this period, see Clark

9. The results are not sensitive to the number of months excluded around the month of Nelson Mendela's election. 
The results for the causal influence of the major developed markets on South Africa during the Apartheid period are presented in panel A of table 6. Panel B of the table provides evidence of bi-directional causality between South Africa and these markets. For the Apartheid period, a five-lag specification is used in the VECM because this lag length minimizes the AIC. The error-correction term in panel A is not significant, implying that during the Apartheid period there was no longrun causal relationship between the South African market and the major developed markets because of the relative isolation of South African economy. Not surprisingly, based on the $F$-statistics, none of these markets (except Canada) appear to Granger-cause South Africa (panel B).

The corresponding VECM results for the post-Apartheid period appear in table 7. Here a ten-lag specification in the VECM is used because it minimizes the AIC. This finding is interesting because it indicates that, during this period, changes in the major equity markets influence the South Africa market over a longer duration. A particularly noteworthy result in panel B is the significance of the error-correction term. This result suggests that following the removal of Apartheid and the attendant integration of South Africa into the world economy, the strength of the long-run relationship between South Africa equity market and the major developed markets has strengthened.

Interestingly, unlike the Apartheid period, all the major equity markets (except Japan) now Granger-cause South Africa. Also, whereas during the Apartheid period only the previous day's changes in the Canadian market Granger-caused contemporaneous changes in the South African market, in the post-Apartheid period the previous day's changes in all the major equity markets, including Japan, Granger-cause contemporaneous changes in the South African market. The results in panel B also suggest that the (bi-directional) causal influence of the South African market on the other markets is different in the postApartheid period, with South Africa also Granger-causing Canada and Germany during this period. Thus, there is clear evidence to suggest that with the removal of the Apartheid regime South Africa has become increasingly integrated with major developed markets. 


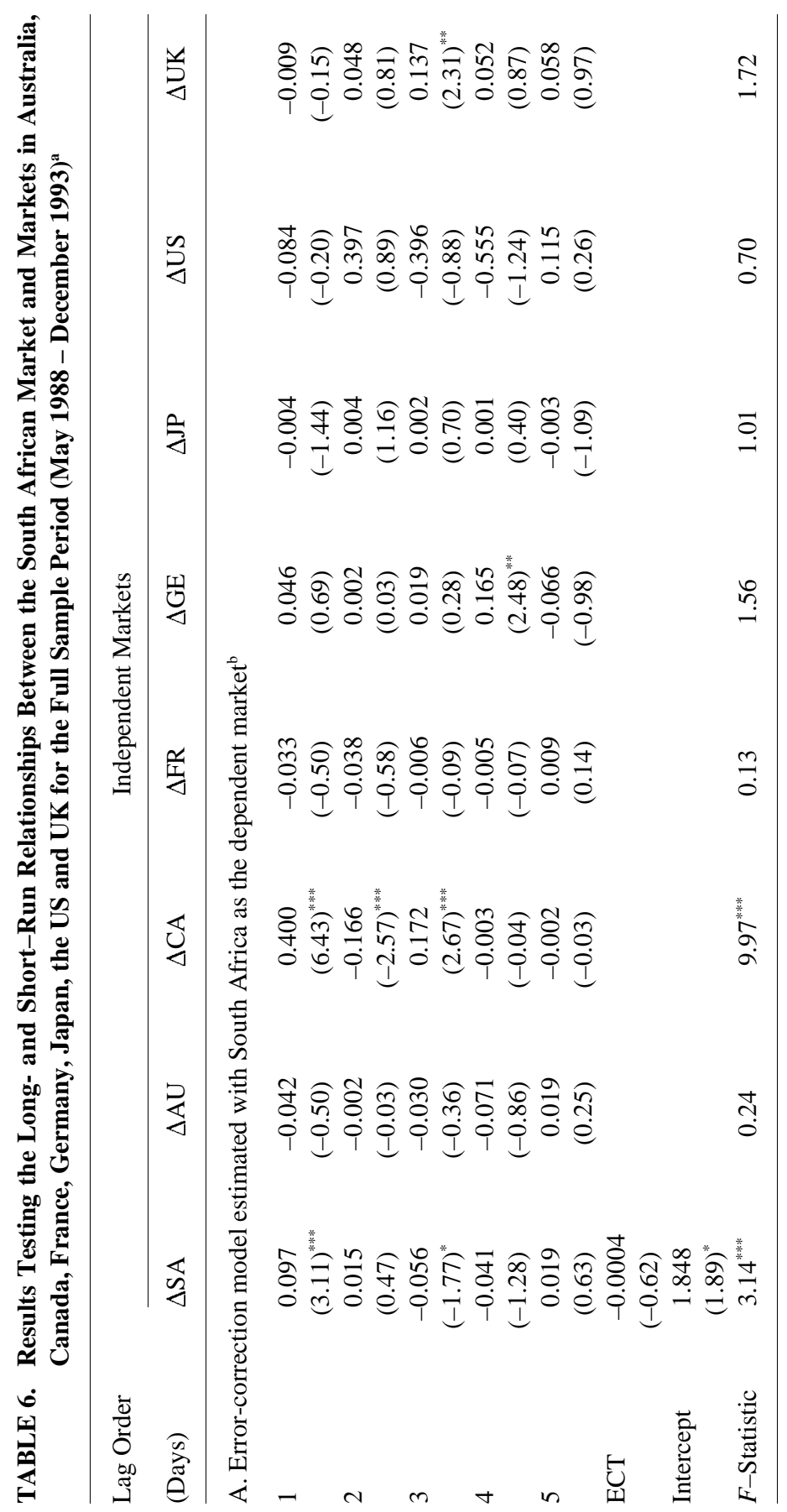




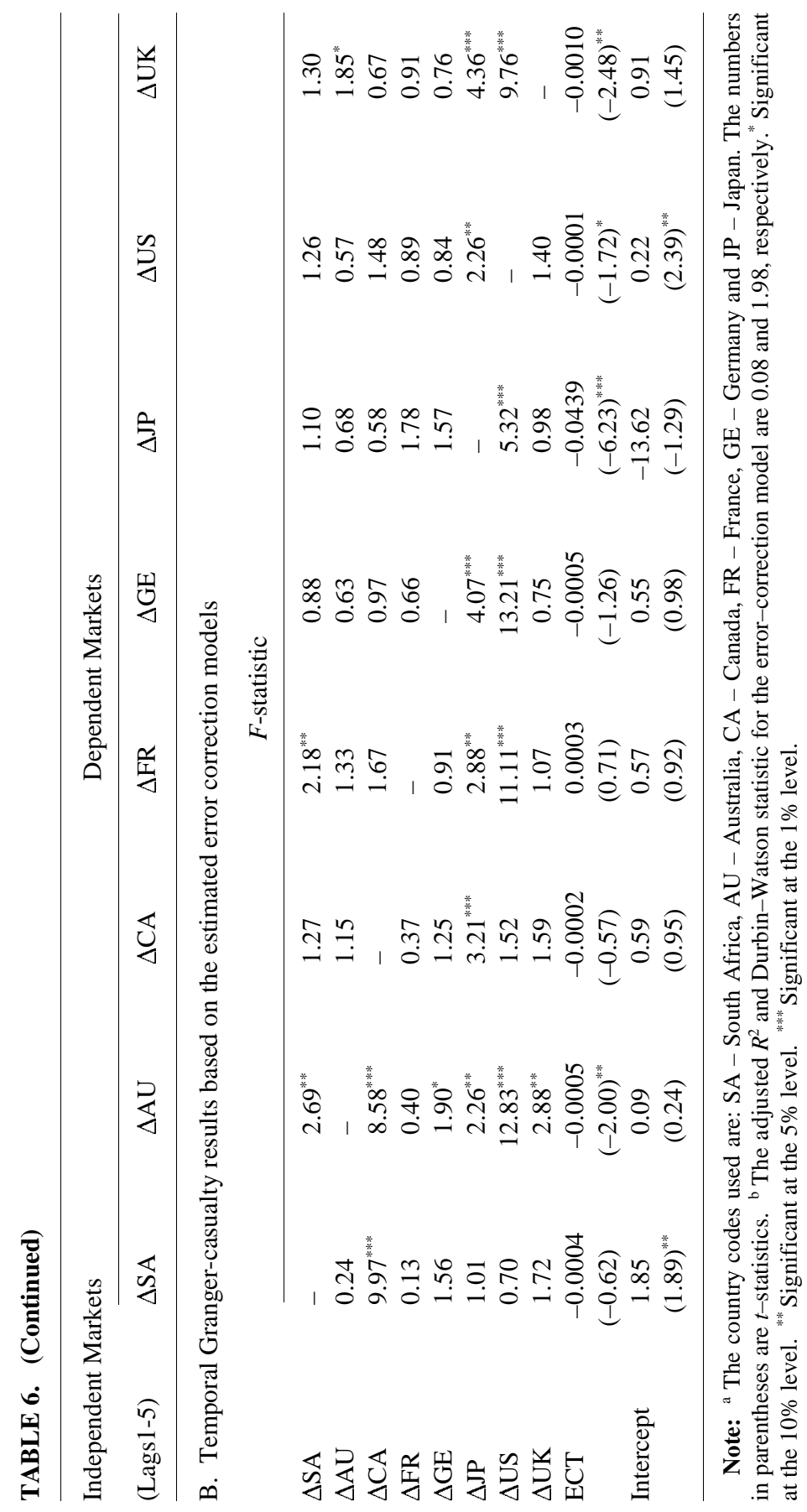




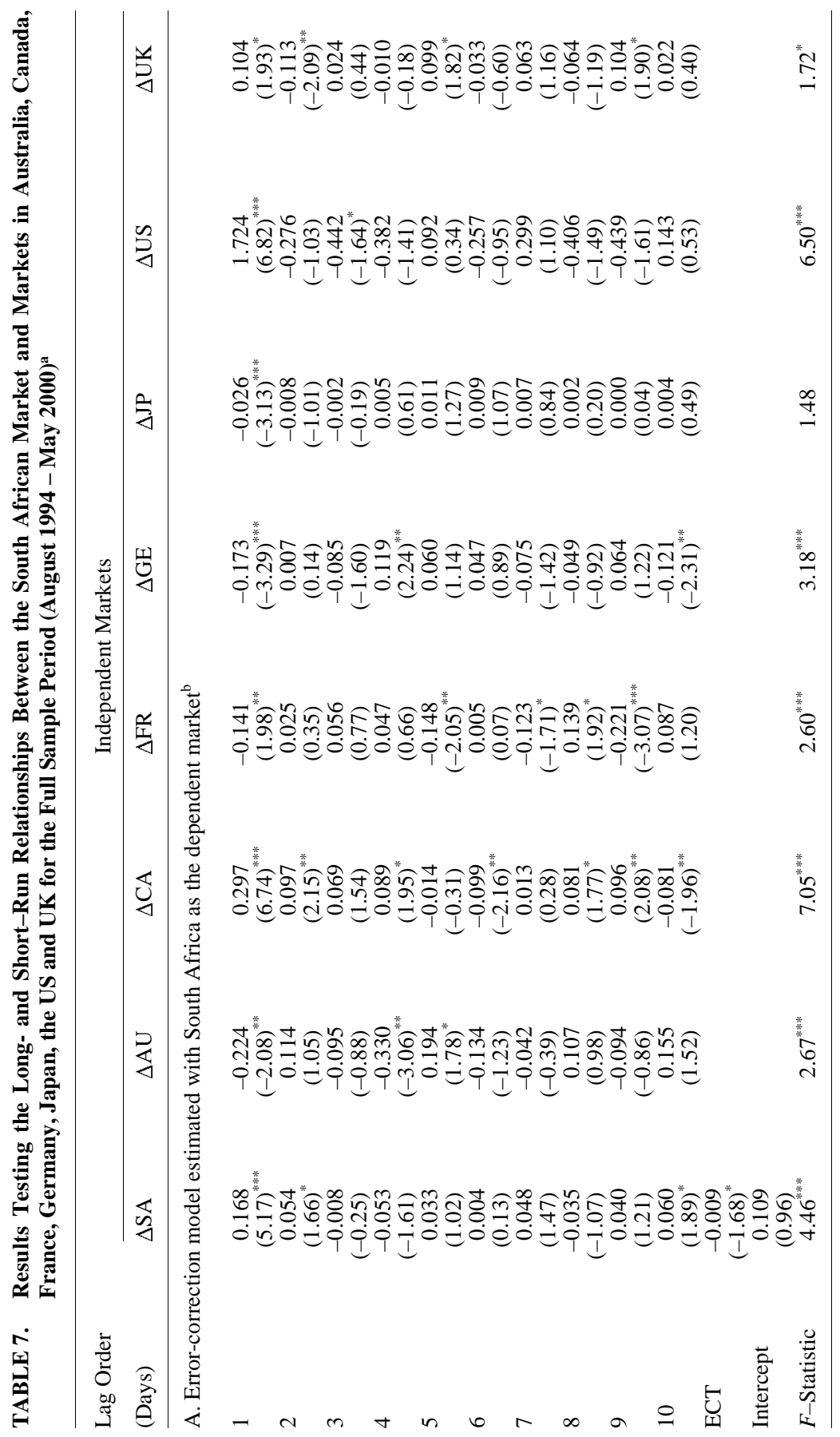




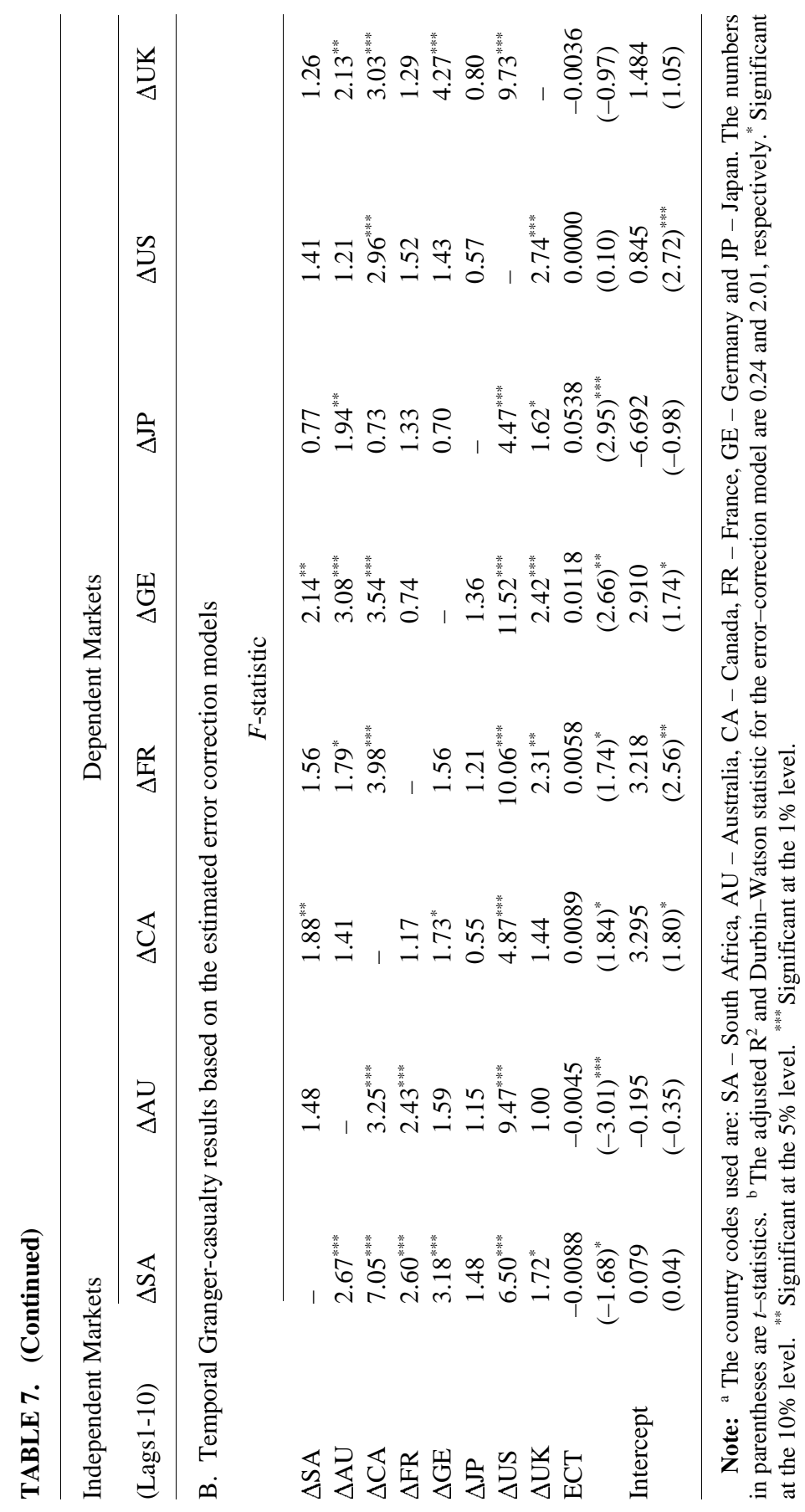




\section{Conclusions}

This paper analyzes the dynamic relationships between the South African market and major world equity markets during May 1988 - May 2000. The results show that a long-run relationship exists between the South African market and the major developed markets. Over the full sample period, all developed markets (except Japan) Granger-cause the South African market, with the US, Canada and Australia being the most influential.

The sub-period analysis shows that during the Apartheid period no long-run causal relationship existed between South Africa and the major developed markets because of South Africa's relative isolation from the world economy. Also, during this period, no market (except Canada) appears to Granger-cause South Africa in the short-run. However, during the post-Apartheid period, a strong and significant long-run equilibrium relationship is observed between the South African market and all the major developed markets, except Japan. These results imply that the South Africa market is now much more economically and financially integrated with the major world equity markets, and that the removal of Apartheid has played a significant role in this process.

\section{References}

Arshanapalli, B., and Doukas, J. 1993. International stock market linkages: Evidence from the pre- and post-October 1987 period, Journal of Banking and Finance 17: 193-208.

Cheung, Y., and Mak, S. 1992. The international transmission of stock market fluctuations between developed markets and the Asian-Pacific markets. Applied Financial Economics 2: 43-47.

Christofi, A.; Pericli, A.; and Nishiyama, K. 2001. Correlation in price changes and volatility of major Asian stock markets. Chapter 6. In Meric, I. and Meric, G. (eds). Global Financial Markets at the Turn of the Century, New York: Pergamon-Elsevier Science.

Clark, R. A. 1998. Africa's Emerging Securities Markets: Developments in Financial Infrastructure, Connecticut: Quorum Books.

Dickey, D. A., and Fuller, W. A. 1979. Distribution of the estimators for autoregressive time series with a unit root. Journal of the American Statistical Association 74: 427-431.

Dickey, D. A., and Fuller, W. A. 1981. Likelihood ratio statistics for 
autoregressive time series with a unit root. Econometrica 49: 1057-1072.

Enders, W. 1995. Applied Economic Time Series. New York: John Wiley \& Sons.

Engle, R., and Granger, C. W. J. 1987. Cointegration and error-correction: Representation, estimation, and testing. Econometrica 55: 251-276.

Engle, R., and White, H. 1999. Cointegration, Causality and Forecasting, London: Oxford University Press.

Eun, C., and Shim, S. 1989. International transmission of stock market movements. Journal of Financial and Quantitative Analysis 24: 241-256.

Gjerde, O., and Sættem, F. 1995. Linkages among European and world stock markets. European Journal of Finance 1: 165-179.

Granger, C. W. J. 1988. Some recent developments in the concept of causality. Journal of Econometrics 39: 199-211.

International Finance Corporation. 1999. Emerging Stock Markets Factbook. Washington: The World Bank.

Janakiramanan, S., and Lamba, A. S. 1998. An empirical examination of linkages between Pacific-Basin stock markets. Journal of International Financial Markets, Institutions and Money 8: 155-173.

Johansen, S. 1988. Statistical analysis of cointegrating vectors. Journal of Economic Dynamics and Control 12: 231-254.

Johansen, S. 1991. Estimation and hypothesis testing of cointegrating vectors in Gaussian vector autoregressive models. Econometrica 59: 1551-1580.

Johansen, S., and Juselius, K., 1990. Maximum likelihood estimation and inference on cointegration with application to the demand for money. Oxford Bulletin of Economics and Statistics 52: 169-209.

Lee, U. 1997. Stock market and macroeconomic policies: New evidence from Pacific-Basin countries, Multinational Finance Journal 1: 272-289.

Liu, Y. A., and Pan, M. 1997. Mean and volatility spillover effects in the U.S. and Pacific-Basin stock markets, Multinational Finance Journal 1: 47-62.

Masih, A. M. M., and Masih, R. 1997. A comparative analysis of the propagation of stock market fluctuations in alternative models of dynamic causal linkages. Applied Financial Economics 7: 59-74.

Meric, I., and Meric, G. 1997. Co-movements of European equity markets before and after the 1987 crash, Multinational Finance Journal 1: 137-152.

Niarchos, N.; Tse, Y.; Wu, C.; and Young, A. 1999. International transmission of information: A study of the relationship between the U.S. and Greek stock markets, Multinational Finance Journal 3: 19-40.

Oldier P., and Solnik, B. 1993. Lessons from international asset allocation. Financial Analysts Journal 49: 63-77.

Osterwald-Lenun, M., 1992. A note with quantiles of asymptotic distribution of maximum likelihood cointegration rank test statistics. Oxford Bulletin of Economics and Statistics 54: 461-472.

Philippatos, G. C.; Christofi, A.; and Christofi, P. C. 1983. The inter-temporal 
stability of stock market relationships: Another view. Financial Management 12: 63-69.

Phillips, P. C., and Perron, P. 1988. Testing for a unit root in time series regression. Biometrika 75: 335-346.

Solnik, B.; Boucrelle, C.; and Le Fur, Y. 1996. International market correlation and volatility. Financial Analysts Journal 52: 17-34. 